\title{
Minute Times Femtogram Per Milliliter Per Milligram Per Gram Per Day
}

National Cancer Institute

\section{Source}

National Cancer Institute. Minute Times Femtogram Per Milliliter Per Milligram Per Gram

Per Day. NCI Thesaurus. Code C117939.

Minute times femtogram per milliliter, divided by milligram per gram per day. 